\title{
Prevalence of Intestinal Parasitic and Bacterial Pathogens in Diarrhoeal and Non-diarroeal Human Stools from Vhembe District, South Africa
}

\author{
A. Samie', R.L. Guerrant' ${ }^{2}$ L. Barrett², P.O. Bessong', E.O. Igumbor', and C.L. Obi ${ }^{3}$ \\ 'Department of Microbiology, University of Venda, Thohoyandou, South Africa, ${ }^{2}$ Center for Global Health, University of Virginia, \\ Charlottesville, USA, and ${ }^{3}$ Academic and Research Directorate, Walter Sisulu University, Nelson Mandela Drive, Eastern Cape, South Africa
}

\section{ABSTRACT}

In the present study, a cross-sectional survey of intestinal parasitic and bacterial infections in relation to diarrhoea in Vhembe district and the antimicrobial susceptibility profiles of isolated bacterial pathogens was conducted. Stool samples were collected from 528 patients attending major public hospitals and 295 children attending two public primary schools and were analyzed by standard microbiological and parasitological techniques. Entamoeba histolytica/E. dispar (34.2\%) and Cryptosporidium spp. (25.5\%) were the most common parasitic causes of diarrhoea among the hospital attendees while Giardia lamblia (12.8\%) was the most common cause of diarrhoea among the primary school children $(\mathrm{p}<0.05)$. Schistosoma mansoni (14.4\%) was more common in non-diarrhoeal samples at both hospitals (16.9\%) and schools (17.6\%). Campylobacter spp. (24.9\%), Aeromonas spp. (20.8\%), and Shigella spp. (8.5\%) were the most common bacterial causes of diarrhoea among the hospital attendees while Campylobacter (12.8\%) and Aeromonas spp. (12.8\%) were most common in diarrhoeal samples from school children. Vibrio spp. was less common (3\% in the hospitals) and were all associated with diarrhoea. Antimicrobial resistance was common among the bacterial isolates but ceftriaxone (91\%) and ciprofloxacin (88.6\%) showed stronger activities against all the organisms. The present study has demonstrated that E. histolytica/dispar, Cryptosporidium, Giardia, and Cyclospora are common parasitic causes of diarrhoea in Vhembe district while Campylobacter spp. and Aeromonas are the most common bacterial causes of diarrhoea in Vhembe district of South Africa.

Key words: Antibiotic resistance; Bacteria; Diarrhoea; Drug resistance, Microbial; Epidemiology; HIV; Parasites; South Africa

\section{INTRODUCTION}

Gastrointestinal infections are major causes of morbidity and mortality throughout the world and particularly in developing countries where mortality rate due to infectious diarrhoea could be as high as $56 \%$ (1). Children and young adults are the most affected, particularly in regions with limited resources and where hygienic measures are not strictly followed (2). In Africa, diarrhoea has been estimated to be responsible for $25-75 \%$ of all

Correspondence and reprint requests should be addressed to:

Dr. A. Samie

Department of Microbiology

University of Venda

Private Bag X5050

Thohoyandou 095, Limpopo Province

South Africa

E-mail: samieamidou@yahoo.com, OR samie.

amidou@univen.ac.za childhood illnesses (3), and episodes of diarrhoea led to about $14 \%$ of outpatient visits and $16 \%$ of hospital admissions and accounted for an average of 35 days of illness per year in children aged less than five years (4). Causes of diarrhoea in endemic areas include a wide variety of bacteria, viruses, and parasites. Intestinal parasites are associated with serious clinical diseases and mortality and are known to cause malnutrition and impairment of physical development in children and affect their growth and learning. It is, thus, necessary to have a fairly-accurate picture of the situation to target interventions in affected areas.

It has been suggested that intestinal parasites occur at unacceptably high levels throughout South Africa (5). However, accurate data on prevalence for the whole country are not currently available. With the exception of mapping being undertaken by researchers in KwaZulu-Natal, the medical geography 
of intestinal parasitic infections is stale, very fragmented, and almost useless for planning, implementing, and monitoring effective interventions (5). In Cape Town, surveys at primary schools in urban and rural communities have revealed that the prevalence of soil-transmitted helminthiasis ranges from $7 \%$ to $83 \%$ (3). However, there is scanty information, if any, on the prevalence of intestinal parasitic infections in Limpopo province.

Bacterial organisms, such as Campylobacter spp., Salmonella spp., Shigella spp., and different groups of enteropathogenic Escherichia coli are well-known as causes of gastrointestinal diseases all over the world. These organisms have been demonstrated in water and stools from the Venda region (6). Infections by most of these organisms can be asymptomatic, or can be treated with rehydration solutions, particularly in the case of viruses and some bacteria. The use of antibiotics might shorten the duration of diarrhoea and limit the shedding of the organisms which otherwise might continue to pollute the environment and pose further risk of transmission of infections. Antibiotics, such as erythromycin and gentamicin, are effective against Campylobacter spp. in some communities (7). However, antimicrobial resistance is an overgrowing problem, and there is a need to monitor the susceptibility of common bacterial isolates to drugs used in the community to provide guidelines for the empirical treatment of bacterial infections. In the present study, we determined the prevalence of intestinal parasitic and bacterial pathogens in diarrhoeal and non-diarrhoeal stools of individuals in Vhembe district and the antimicrobial susceptibility of important bacterial isolates.

\section{MATERIALS AND METHODS}

\section{Study sites and sample collection}

The study was a cross-sectional survey of intestinal parasitic and bacterial pathogens and was conducted in Vhembe district, South Africa, from October 2003 to April 2005. De-identified stool samples were randomly collected from pupils of two public primary schools and from patients attending three main public hospitals in the region, including Elim, Vhufuli and Tshilidzini hospitals. At the primary schools, the teachers distributed sterile plastic bottles to the pupils whose parents consented to participate in the study. The bottles were brought home, and the samples were collected the next morning. The samples were then transported in cooler bags to the Microbiology Laboratory at the University of Venda, in Thohoyandou, within two hours of collection. Samples not analyzed the same day were kept in the freezer at $-20^{\circ} \mathrm{C}$. In total, 823 stool samples were collected. Five hundred twentyeight samples were collected from patients attending the three public hospitals in Vhembe district, with abdominal complaints or diarrhoea (based on the physical presentation of the sample) while 295 were from apparently asymptomatic pupils attending two public primary schools. The samples were further tested for parasitic and bacterial organisms. No attempt was made to detect viruses from the stool samples.

\section{Microscopic examination}

A wet mount was prepared for each sample and observed under the light microscope for eggs and trophozoites of various parasites. The stool samples were further treated by the formalin/ethyl acetate concentration procedure, and a permanent slide was prepared for each sample to confirm the results. Only samples that gave positive results for each organism by both the methods were considered positive. Doubtful results-positive with only one method-were not considered.

\section{Detection of Cryptosporidium and other coccidian oocysts}

The modified Ziehl Neelson staining procedure was used for detecting Cryptosporidium and other coccidian oocysts, including Cyclospora cayetanensis and Isospora belii, from the stool samples.

\section{Bacterial isolation and identification}

The bacterial organisms, including Salmonella spp., Aeromonas spp., Plesiomonas shigelloides, Vibrio spp, and Shigella species, were isolated using standard microbiological methods as previously described (6), with some modifications for Campylobacter spp. isolated using the filter method as described in the Cape Town protocol (8) and confirmed by the haemagglutination test-kit-'Campy dry spot'-from Oxoid, England, as recommended by the manufacturer.

\section{Antimicrobial susceptibility of bacterial isolates}

The antimicrobial susceptibility of five bacterial species to 14 antibiotics was determined using the Kirby-Bauer disc-diffusion method with standard antibiotic discs according to the National Committee on Clinical Laboratory Standards (NCCL), now known as Clinical and Laboratory Standard Institutes (ICLS) standards. The diameters of the zones of inhibition were measured with a calliper in $\mathrm{mm}$, and the results were interpreted according to the recommendations of the NCCLS for Enterobacteriaceae (9). 


\section{Ethical issues}

The Research and Ethics Committee of the University of Venda, South Africa, approved the research protocol. Authorizations to collect samples from schools and public-health institutions were obtained from the Department of Health and of Education, Limpopo province, South Africa. Informed consent was obtained from all the participants either directly or through their legal and competent guardians.

\section{Statistical analysis}

Statistical analysis was performed by the chi-square test. The differences were considered significant when the $\mathrm{p}$ value was less than 0.05 .

\section{RESULTS}

\section{Demographic information of study population}

The patients were aged 1-88 year(s), with the median age at the hospital being 26.4 years. At the schools, the children were aged 5-15 years, with the median age at 11.8 years. At the hospital, 290 (55\%) of the study subjects were female while 238 (45\%) were male. The large majority $(69.9 \%)$ of the study subjects were aged 10-39 years. Of the 528 samples, 269 (51\%) were diarrhoeal (based on the physical presentation of the sample) while 259 (49\%) were non-diarrhoeal (formed). Diarrhoeal samples were obtained from all age-groups. However, diarrhoea was more common among children (78\%) aged less than five years. At the schools, 165 (56\%) pupils were female, and 130 (44\%) were male. Of the 295 samples collected from the schools, 39 (13.2\%) were diarrhoeal (unformed), with a higher percentage among pupils aged less than five years (29\%) compared to those aged more than five years $(11.8 \%)$.

\section{Prevalence of parasitic infections}

Intestinal parasites were found in 560 (68\%) of the samples, with different parasitic profiles between the patients attending the hospitals and the school children. At the hospitals, E. histolytica/dispar (34.2\%) were the most common organisms found in diarrhoeal stool samples, followed by Cryptosporidium (25.2\%) and Blastocystis hominis (17.8\%) compared to $9.3 \%, 17.7 \%$, and $1.9 \%$ respectively in non-diarrhoeal samples $(\mathrm{p}<0.05$ for all the three organisms). G. lamblia and C. cayetanensis were also associated with diarrhoea among hospital attendees $(\mathrm{p}<0.05)$. At the schools, E. histolytica/dispar and Cryptosporidium were not associated with diarrhoea ( $>0.05)$, although Cryptosporidium was common in this population $(17.9 \%$ in diarrhoeal samples and $14.4 \%$ in non-diarrhoeal samples). G. lamblia (12.8\%), Cyclospora (7.7\%), and Isospora (5.1\%) were associated with diarrhoeal samples obtained from the primary school children $(\mathrm{p}<0.05)$. Polyparasitism was more common in the hospitals (39.6\%) compared to the schools (23\%). Of all the infected individuals, 283 (51\%) were infected with one parasite while 277 (49\%) were infected with many parasites. Table 1 indicates the prevalence of intestinal parasitic organisms in stools of the study subjects with or without diarrhoea.

Occurrence of bacterial pathogens in stool samples

One or more bacterial pathogens were detected in 467 (56.7\%) samples. Campylobacter spp. were the most commonly-isolated organisms from diarrhoeal stools at both hospitals (24.9\%) and primary schools (12.8\%), followed by Aeromonas spp., with $20.8 \%$ occurrence in the hospitals and $12.8 \%$ in the schools. These organisms were also isolated in non-diarrhoeal samples from the hospitals and in the schools. Vibrio spp. were less commonly isolated from the hospitals (3\%) and in the schools $(0.6 \%)$. Table 2 describes the occurrence of the different bacterial organisms in diarrhoeal and nondiarrhoeal samples. Mixed infections with more than one bacterial species were more often found in the samples from the hospitals (21.7\%) than in the samples from the schools $(4 \%)(\mathrm{p}<0.05)$.

\section{Antimicrobial susceptibility profiles of five bacterial species}

Table 3 represents the antimicrobial susceptibility profiles of five different bacterial species tested: Aeromonas spp., Campylobacter spp., Salmonella spp., Shigella spp., and Vibrio spp. against 14 antibiotics. Most isolates of Plesiomonas could not be recovered and were, thus, not available for antimicrobial susceptibility. Cloxacillin, ampicillin, and erythromycin were the least effective antibiotics, with an overall susceptibility less than 30\%. Ceftriaxone was the most effective antibiotic against all the organisms tested, except the Vibrio spp., against which ciprofloxacin was most effective. Generally, ceftriaxone, ciprofloxacin, ofloxacin, gentamicin, kanamycin, and lomefloxacin were more effective on all the bacterial pathogens tested with overall susceptibility of $91 \%, 89 \%, 86 \%, 81 \%, 78 \%$, and $74 \%$ respectively. Resistance to more than two antibiotics was common and was observed in four (22.2\%) Vibrio isolates, 22 (22.4\%) Campylobacter isolates, 18 (24.3\%) Aeromonas isolates, 7 (18.9\%) Salmonella isolates, and 16 (31.4\%) Shigella isolates. 


\begin{tabular}{|c|c|c|c|c|c|c|c|c|}
\hline \multirow[b]{2}{*}{$\begin{array}{l}\text { Parasitic } \\
\text { organism }\end{array}$} & \multicolumn{4}{|c|}{ Samples from hospital $(\mathrm{n}=528)$} & \multicolumn{4}{|c|}{ Samples from schools $(n=295)$} \\
\hline & $\begin{array}{c}\text { Diarrhoeal } \\
(\mathrm{n}=269) \\
\text { No. }(\%)\end{array}$ & $\begin{array}{c}\text { Non- } \\
\text { diarrhoeal } \\
(\mathrm{n}-259) \\
\text { No. }(\%)\end{array}$ & $\begin{array}{c}\text { Total } \\
\text { no. } \\
(\%)\end{array}$ & $\begin{array}{l}\text { Signifi- } \\
\text { cance } \\
(\mathrm{p} \\
\text { value })\end{array}$ & $\begin{array}{c}\text { Diarrhoeal } \\
(\mathrm{n}=39) \\
\text { No. }(\%)\end{array}$ & $\begin{array}{c}\text { Non- } \\
\text { diarrhoeal } \\
(\mathrm{n}=256) \\
\text { No. }(\%)\end{array}$ & $\begin{array}{l}\text { Total } \\
\text { no. } \\
(\%)\end{array}$ & $\begin{array}{l}\text { Signifi- } \\
\text { cance } \\
(p \\
\text { value })\end{array}$ \\
\hline $\begin{array}{l}\text { Entamoeba } \\
\text { histolytica/ } \\
\text { E. dispar }\end{array}$ & $\begin{array}{c}92 \\
(34.2)\end{array}$ & $\begin{array}{c}24 \\
(9.3)\end{array}$ & $\begin{array}{l}116 \\
(22)\end{array}$ & $<0.0001$ & $\begin{array}{c}3 \\
(7.7)\end{array}$ & $\begin{array}{c}7 \\
(2.7)\end{array}$ & $\begin{array}{c}10 \\
(3.4)\end{array}$ & 0.111 \\
\hline $\begin{array}{l}\text { Cryptospo- } \\
\text { ridium spp. }\end{array}$ & $\begin{array}{c}68 \\
(25.3)\end{array}$ & $\begin{array}{c}46 \\
(17.7)\end{array}$ & $\begin{array}{c}104 \\
(19.7)\end{array}$ & 0.036 & $7(17.9)$ & $37(14.4)$ & $\begin{array}{c}44 \\
(14.9)\end{array}$ & 0.568 \\
\hline $\begin{array}{l}\text { Blastocystis } \\
\text { hominis }\end{array}$ & $\begin{array}{c}48 \\
(17.8)\end{array}$ & $\begin{array}{c}5 \\
(1.9)\end{array}$ & $\begin{array}{c}53 \\
(10)\end{array}$ & $<0.0001$ & $\begin{array}{c}3 \\
(7.7)\end{array}$ & $\begin{array}{c}5 \\
(2)\end{array}$ & $\begin{array}{c}8 \\
(2.7)\end{array}$ & 0.040 \\
\hline $\begin{array}{l}\text { Entamoeba } \\
\text { coli }\end{array}$ & $\begin{array}{c}36 \\
(13.4)\end{array}$ & $\begin{array}{c}29 \\
(11.2)\end{array}$ & $\begin{array}{c}65 \\
(12.3)\end{array}$ & 0.445 & $\begin{array}{c}2 \\
(5.1)\end{array}$ & $\begin{array}{c}12 \\
(4.7)\end{array}$ & $\begin{array}{c}14 \\
(4.7)\end{array}$ & 0.904 \\
\hline $\begin{array}{l}\text { Entamoeba } \\
\text { hartmanii }\end{array}$ & $\begin{array}{l}19 \\
(7)\end{array}$ & $\begin{array}{c}11 \\
(4.2)\end{array}$ & $\begin{array}{c}30 \\
(5.6)\end{array}$ & 0.162 & $\begin{array}{c}3 \\
(7.7)\end{array}$ & $\begin{array}{c}5 \\
(2)\end{array}$ & $\begin{array}{c}8 \\
(2.7)\end{array}$ & 0.040 \\
\hline $\begin{array}{l}\text { Giardia } \\
\text { lamblia }\end{array}$ & $\begin{array}{c}41 \\
(15.2)\end{array}$ & $\begin{array}{l}13 \\
(5)\end{array}$ & $\begin{array}{c}54 \\
(10.2)\end{array}$ & 0.0001 & $\begin{array}{c}5 \\
(12.8)\end{array}$ & $\begin{array}{c}7 \\
(2.7)\end{array}$ & $\begin{array}{c}12 \\
(4.1)\end{array}$ & 0.003 \\
\hline $\begin{array}{l}\text { Hymenolepis } \\
\text { nana }\end{array}$ & $\begin{array}{l}16 \\
(6)\end{array}$ & $\begin{array}{l}13 \\
(5)\end{array}$ & $\begin{array}{c}29 \\
(5.5)\end{array}$ & 0.640 & $\begin{array}{c}0 \\
(0)\end{array}$ & $\begin{array}{c}2 \\
(0.8)\end{array}$ & $\begin{array}{c}2 \\
(0.6)\end{array}$ & 0.580 \\
\hline $\begin{array}{l}\text { Cyclospora } \\
\text { cayetanensis }\end{array}$ & $\begin{array}{c}32 \\
(11.9)\end{array}$ & $\begin{array}{c}6 \\
(2.3)\end{array}$ & $\begin{array}{c}38 \\
(7.2)\end{array}$ & 0.0001 & $\begin{array}{c}3 \\
(7.7)\end{array}$ & $\begin{array}{c}0 \\
(0)\end{array}$ & $\begin{array}{c}3 \\
(1.0)\end{array}$ & $<0.001$ \\
\hline Isospora belli & $\begin{array}{c}16 \\
(5.9)\end{array}$ & $\begin{array}{c}9 \\
(3.4)\end{array}$ & $\begin{array}{c}25 \\
(4.7)\end{array}$ & 0.181 & $\begin{array}{c}2 \\
(5.1)\end{array}$ & $\begin{array}{c}0 \\
(0)\end{array}$ & $\begin{array}{c}2 \\
(0.7)\end{array}$ & $<0.001$ \\
\hline $\begin{array}{l}\text { Enterobius } \\
\text { vermicularis }\end{array}$ & $\begin{array}{c}24 \\
(8.9)\end{array}$ & $\begin{array}{c}19 \\
(7.3)\end{array}$ & $\begin{array}{c}43 \\
(8.1)\end{array}$ & 0.505 & $\begin{array}{c}3 \\
(7.7)\end{array}$ & $\begin{array}{c}4 \\
(1.6)\end{array}$ & $\begin{array}{c}7 \\
(2.3)\end{array}$ & 0.019 \\
\hline $\begin{array}{l}\text { Ascaris } \\
\text { lumbricoides }\end{array}$ & $\begin{array}{c}28 \\
(10.4)\end{array}$ & $\begin{array}{c}22 \\
(8.5)\end{array}$ & $\begin{array}{c}50 \\
(9.4)\end{array}$ & 0.453 & $\begin{array}{c}4 \\
(10.2)\end{array}$ & $\begin{array}{c}19 \\
(7.4)\end{array}$ & $\begin{array}{c}23 \\
(7.8)\end{array}$ & 0.539 \\
\hline $\begin{array}{l}\text { Trichuris } \\
\text { trichiura }\end{array}$ & $\begin{array}{c}28 \\
(10.4)\end{array}$ & $\begin{array}{c}17 \\
(6.5)\end{array}$ & $\begin{array}{c}45 \\
(8.5)\end{array}$ & 0.114 & $\begin{array}{c}2 \\
(5.1)\end{array}$ & $\begin{array}{c}4 \\
(1.6)\end{array}$ & $\begin{array}{c}6 \\
(2.03)\end{array}$ & 0.142 \\
\hline Hookworms & $\begin{array}{c}31 \\
(11.5)\end{array}$ & $\begin{array}{c}28 \\
(10.4)\end{array}$ & $\begin{array}{c}59 \\
(11.1)\end{array}$ & 0.789 & $\begin{array}{c}5 \\
(12.8)\end{array}$ & $\begin{array}{l}18 \\
(7)\end{array}$ & $\begin{array}{c}23 \\
(7.7)\end{array}$ & 0.209 \\
\hline $\begin{array}{l}\text { Schistosoma } \\
\text { mansoni }\end{array}$ & $\begin{array}{c}32 \\
(11.9)\end{array}$ & $\begin{array}{c}44 \\
(16.9)\end{array}$ & $\begin{array}{c}76 \\
(14.4)\end{array}$ & 0.096 & $\begin{array}{c}4 \\
(10.3)\end{array}$ & $\begin{array}{c}45 \\
(17.6)\end{array}$ & $\begin{array}{c}49 \\
(16.6)\end{array}$ & 0.252 \\
\hline $\begin{array}{l}\text { Multiple } \\
\text { infections }\end{array}$ & $\begin{array}{l}124 \\
(46)\end{array}$ & $\begin{array}{c}85 \\
(32.8)\end{array}$ & $\begin{array}{c}209 \\
(39.6)\end{array}$ & & $\begin{array}{c}12 \\
(30.8)\end{array}$ & $\begin{array}{c}56 \\
(21.9)\end{array}$ & $\begin{array}{l}68 \\
(23)\end{array}$ & \\
\hline
\end{tabular}

\section{DISCUSSION}

The objectives of the study were to determine the prevalence of intestinal parasitic and bacterial infections in relation to diarrhoeal symptoms and to determine the antimicrobial susceptibility profiles of the bacterial isolates in two population groups in Vhembe district, Limpopo province, South Africa. The prevalence and the profiles of intestinal infections vary among continents and even within countries or subregions. We found that $E$. histolytica/dispar, Cryptosporidium spp., S. mansoni, hookworm, B. Hominis, and G. lamblia were the most common parasitic agents in the study population, with infection rates more than $10 \%$ which is higher than those described in Indonesia, for example, where B. hominis $(6.52 \%), E$. (3.62\%), and G. lamblia (3.62\%) were most common (10). In Karnataka, India, Ascaris lumbricoides was the single predominant species in both rural (79.2\%) and urban (56\%) populations (11). In Cape Town, South Africa, higher rates of infection were described for Ascaris (24.8\%), Trichuris (50.6\%), Hymenolepis nana (2.2\%), Enterobius (0.6\%) Giardia (17.3\%), hookworm (0.08\%), and Trichostrongylus (0.1\%) among children attending nine schools in a low-income 


\begin{tabular}{|lcccccccccc|}
\hline \multicolumn{8}{|c|}{ Table 2. Isolation rates of bacterial pathogens from stools from hospitals and schools in the Venda } \\
region of South Africa
\end{tabular}

Table 3. Susceptibility profiles of isolates to 14 different antibiotics

$\begin{array}{lllllllllllllll}\begin{array}{l}\text { Bacterial } \\ \text { organism }\end{array} & \text { Lom } & \text { Aug } & G & \mathrm{~T} & \mathrm{E} & \mathrm{Cip} & \mathrm{Cx} & \mathrm{K} & \mathrm{C} & \mathrm{O} x & \mathrm{NA} & \mathrm{Ap} & \text { Cro } & \text { Lzd }\end{array}$

Aeromonas spp.

$\begin{array}{lllllllllllllll}(\mathrm{n}=74) & 86 & 64 & 76 & 71 & 50 & 86 & 0 & 86 & 50 & 83 & 53 & 14 & 92 & 38\end{array}$

Salmonella spp.

$\begin{array}{lllllllllllllll}(\mathrm{n}=37) & 72 & 50 & 74 & 40 & 0 & 90 & 0 & 75 & 50 & 80 & 50 & 10 & 94 & 42\end{array}$

Campylobacter

$\begin{array}{lllllllllllllll}\text { spp. (n=98) } & 70 & 56 & 79 & 65 & 5 & 89 & 0 & 70 & 21 & 82 & 46 & 13 & 92 & 28\end{array}$

Vibrio spp.

$\begin{array}{lllllllllllllll}(\mathrm{n}=18) & 65 & 59 & 82 & 63 & 63 & 94 & 6 & 79 & 69 & 97 & 54 & 22 & 85 & 34\end{array}$

$\begin{array}{lllllllllllllll}\begin{array}{l}\text { Shigella spp. } \\ (\mathrm{n}=51)\end{array} & \mathrm{ND} & \mathrm{ND} & 96 & 38 & 28 & 84 & 2 & 81 & 55 & 86 & 68 & 36 & 92 & \mathrm{ND}\end{array}$

Overall

$\begin{array}{lllllllllllllll}\text { susceptibility } & 74 & 57 & 81 & 55 & 29 & 89 & 1 & 78 & 47 & 86 & 54 & 19 & 91 & 36\end{array}$

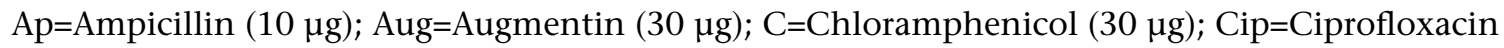
$(5 \mu \mathrm{g})$; Cro=Ceftriaxone $(30 \mu \mathrm{g}) ; \mathrm{Cx}=$ Cloxacillin $(5 \mu \mathrm{g})$; $\mathrm{E}=$ Erythromycin $(15 \mu \mathrm{g}) ; \mathrm{G}=$ Gentamycin $(120 \mu \mathrm{g}) ; \mathrm{K}=$ Kanamycin $(30 \mu \mathrm{g})$; Lom=Lomefloxacin $(10 \mu \mathrm{g})$; Lzd= Linezolid $(10 \mu \mathrm{g})$; NA=Nalidixic acid $(30 \mu \mathrm{g}) ; \mathrm{ND}=$ Not done; OfX=Ofloxacin $(5 \mu \mathrm{g}) ; \mathrm{T}=$ Tetracycline $(30 \mu \mathrm{g})$

but well-serviced community independent of diarrhoeal symptoms (12). Of interest was the finding of $C$. cayetanensis in association with diarrhoea in our study. Similar results have been obtained from other parts of Africa, such as Nigeria and Tanzania $(13,14)$. However, we have not been able to find any documentation on infections by this organism in South Africa, and knowledge on its transmission pattern is not clearly defined.
The high prevalence of organisms, such as E. histolytica/dispar, Cryptosporidium, and Giardia, among the young people found in the present study is of concern and deserves careful consideration in the development of health policies in the region. This is even more important because of the lasting detrimental effects of enteric infections that occur during early childhood on later physical and cognitive development and in patients with acquired 
immunodeficiency syndrome on the absorption of antiretroviral drugs which are increasingly being recognized (2). Recent studies in Uganda have also indicated a strong association between the chronic infection of the gastrointestinal tract and the likelihood of developing tumors (15). With the increasing prevalence of HIV infections in the region, investigations on the role of these pathogens in the progression of disease among HIV patients is recommended since the burden of multiple infections might overwhelm the immuno-suppressed host and accelerate the evolution towards the AIDS state (16).

The global occurrence and increasingly frequent presence of bacterial pathogens, such as Campylobacter spp., Aeromonas spp., and E. coli, in the form of faecal coliforms in ambient and source waters suggest that the understanding of their distribution is important for public-health efforts to prevent and control outbreaks. Mostly-encountered bacterial pathogens included Campylobacter spp., Aeromonas spp., and Salmonella spp. Previous studies on these organisms in the region have not compared the rate among diarrhoeal and non-diarrhoeal samples. A recent study in Gaza also identified $E$. histolytica/dispar (15) and Campylobacter coli/jejuni (5) among other organisms as major cause of acute diarrhoea in Palestinian children aged less than five years (17). This study has, thus, revealed that these bacterial agents were significantly associated with diarrhoea in the region, with increasing resistance to antibiotic agents, such as erythromycin for Campylobacter spp., tetracycline for Shigella, and ampicillin for Salmonella spp. compared to previous studies (6). In Ethiopia, the susceptibility pattern of diarrhoea-causing bacteria, including Yersinia enterocolitica, Shigella, E. coli, and Salmonella, to gentamicin, nalidixic acid, norfloxacin, and polymyxin B was greater than $90 \%$ for the tested strains while resistance to cephalothin, ampicillin, and tetracycline was greater than $50 \%$ (18). In the present study, we found that ampicillin was not active against most organisms tested while gentamicin was effective against most organisms tested. The regular monitoring of antimicrobial resistance profiles is, thus, useful for understanding the resistance development trends in each group of organisms and is helpful in the empirical implementation of antibiotic regiments.

The results obtained in this study clearly indicate that many enteropathogenic bacteria and parasites are endemic in Vhembe district of South Africa. Emerging pathogens, such as Cryptosporidium and C. cayetanensis, which are resistant to chlorine disinfection, were found in the hospital patients and school children. All together, these pathogens can be transmitted through contaminated water or food, or poor hygiene. Factors that might be associated with the transmission of these pathogens may include low socioeconomic status, low level of education, use of unchlorinated well- or river-water, and a low level of personal hygiene. These factors reflect the living conditions, lifestyle, and environmental conditions of the local population. The level of gastrointestinal disease associated with the faecal-oral route of transmission could be decreased significantly by implementing relatively simple strategies, such as better wastewater treatment and hygiene education. Studies in Indonesia suggested that a systematic and sustained effort to teach children to (a) avoid certain types of behaviour that favours infection and (b) practise good personal hygiene are the best approaches to significant and enduring reduction of the scourge of intestinal parasitism (19). Thus, there is a great need to upgrade water-treatment procedures and sanitation standards which do not seem to be well-handled in Thohoyandou and in many other agglomerations in the region as indicated by previous research (6). Such strategies could alleviate a great deal of unnecessary sufferings and loss of productivity, reduce the number of lives lost to these diseases, and result in significant savings in healthcare costs. Further studies on the relative impact of these infections on the susceptibility to HIV transmission and child education and welfare will increase our understanding of the complex intricacies of endemic diseases and health outcome in the region.

In conclusion, the present study has demonstrated that protozoan organisms, such as E. histolytica/dispar, Cryptosporidium, Giardia, and Cyclospora, are common parasitic causes of diarrhoea in Vhembe district while Campylobacter spp. and Aeromonas are the most common bacterial causes of diarrhoea in Vhembe district of South Africa. This is the first report on the occurrence of helminthic infections in the region, showing the frequent occurrence of $A$. lumbricoides, hookworm, Trichuris trichiura, and $S$. mansoni in Vhembe district of South Africa. Further studies are warranted to understand the impact of these organisms on child health and their possible implication in HIV transmission and pathogenicity which constitute a growing threat to health in the region.

\section{ACINOWLEDGEMENTS}

Part of this study was funded by the International Society for Infectious Diseases and the National Research Foundation of South Africa. Additional 
support was provided by the Ellison Medical Foundation's grant to the Center for Global Health, University of Virginia, Charlottesville, VA, USA. The authors are grateful to the officials of the primary schools and the hospitals for their collaboration in the sample collection.

\section{REFERENCES}

1. World Health Organization. World health report 2004: changing history. Geneva: World Health Organization, 2004. $200 \mathrm{p}$.

2. Guerrant RL, Oria R, Bushen OY, Patrick PD, Houpt E. Global impact of diarrheal diseases that are sampled by travelers: the rest of the hippopotamus. Clin Infect Dis 2005;41:S524-30.

3. Kirkwood BR. Diarrhoea. In: Feachem RG, Jamison DT, editors. Disease and mortality in sub-Saharan Africa. New York, NY: Oxford University Press, 1991:13457

4. Greenwood BM, Greenwood AM, Bradley AK, Tulloch S, Hayes R, Oldfield FS. Deaths in infancy and early childhood in a well-vaccinated, rural, West African population. Ann Trop Paediatr 1987;7:91-9.

5. Fincham JE, Jackson TFHG, Schoeman S, Evans AC, Markus MB, Mwamba JC. Intestinal parasites in children: the need for community-based interventions. Tygerberg: Medical Research Council, 1997:1-2. (MRC policy brief no. 3)

6. Obi CL, Bessong PO, Momba MNB, Potgieter N, Samie A, Igumbor EO. Profiles of antibiotic susceptibilities of bacterial isolates and physicochemical quality of water supply in rural Venda communities, South Africa. Water SA 2004;30:515-20.

7. Bester LA, Essack SY. Prevalence of antibiotic resistance in Campylobacter isolates from commercial poultry suppliers in KwaZulu-Natal, South Africa. J Antimicrob Chemother 2008;62:1298-300.

8. Le Roux E, Lastovica AJ. The Cape Town protocol: how to isolate the most campylobacters for your dollar, pound, franc, yen, etc. In: Lastovica AJ, Newell DG, Lastovica EE, editos. Campylobacter, Helicobacter and related organisms. Cape Town: University of Cape Town, 1998:30-3.

9. National Committee for Clinical Laboratory Standards. Performance standards for antimicrobial disc susceptibility test. Approved standard. 6th ed. Wayne, PA: National Committee for Clinical Laboratory Standards, 2003:12-3. (NCCLS document no. M7A6).

10. Simadibrata M, Tytgat GN, Yuwono V, Daldiyono, Lesmana LA, Syam AF et al. Microorganisms and parasites in chronic infective diarrhea. Acta Med Indones 2004;36:211-4.

11. Chandrasekhar MR, Nagesha CN. Intestinal helminthic infestation in children. Indian J Pathol Microbiol 2003;46:492-4.

12. Adams VJ, Markus MB, Adams JFA, Jordaan E, Curtis B, Dhansay MA et al. Paradoxical helminthiasis and giardiasis in Cape Town, South Africa: epidemiology and control. Afr Health Sci 2005;5:276-80.

13. Alakpa GE, Fagbenro-Beyioku AF. Cyclospora cayetanensis and intestinal parasitic profile in stool samples in Lagos, Nigeria. Acta Protozool 2002;41:221-7.

14. Cegielski JP, Ortiga YR, McKee S, Madden JF, Gaido L, Schwartz DA et al. Cryptosporidium, Enterocytozoon and Cyclospora infections to pediatric and adult patients with diarrhea in Tanzania. Clin Infect Dis 1999;28:314-21.

15. Waku M, Napolitano L, Clementini E, Staniscia T, Spagnolli C, Andama A et al. Risk of cancer onset in sub-Saharan Africans affected with chronic gastrointestinal parasitic diseases. Int J Immunopathol Pharmacol 2005;18:503-11.

16. Silva CV, Ferreira MS, Borges AS, Costa-Cruz JM. Intestinal parasitic infections in HIV/AIDS patients: experience at a teaching hospital in central Brazil. Scand J Infect Dis 2005;37:211-5.

17. Abu-Elamreen FH, Abed AA, Sharif FA. Viral, bacterial and parasitic etiology of pediatric diarrhea in Gaza, Palestine. Med Princ Pract 2008;17:296-301.

18. Andualem B, Geyid A. Antimicrobial responses of Yersinia enterocolitica isolates in comparison to other commonly encountered bacteria that causes diarrhoea. East Afr Med J 2005;82:241-6.

19. Albright JW, Hidayati NR, Basaric-Keys J. Behavioral and hygienic characteristics of primary schoolchildren which can be modified to reduce the prevalence of geohelminth infections: a study in central Java, Indonesia. Southeast Asian J Trop Med Public Health 2005;36:629-40. 